K. G. Smedstad MB, CH B, FRCPC

D. H. Morison $\mathrm{MB}, \mathrm{CH} B$, FRCPC

\title{
A comparative study of continuous and intermittent epidural analgesia for labour and delivery
}

\begin{abstract}
This study compares a continuous infusion technique with intermittent "top-up" doses using 0.25 per cent bupivacaine for epidural aralgesia for labour and delivery in healthy primiparous patients. Sixty women were randomized into two groups, $A$ (continuous) and $B$ (intermittent). Twenty-eight patients in Group $A$ and 29 in Group B completed the study. We compared the groups with regard to satisfaction with pain relief for both labour and delivery as measured by a Visual Analogue Scale on five occasions during and after parturition. There was no difference between groups at any of the five stages. The difference in pain scores before the epidural and after the epidural was significant for both groups ( $p<0.001$ ). The incidence of missed segments. degrees of motor block, height of sensory black, length of tabour and fetal outcome were similar in both groups. Plasma bupivacaine levels were measured in six patients in each group. Mothers in Group A received more drug than those in Group $B(p<0.01)$ but plasma bupivacaine levels remained low in the mother and the umbilical cord samples in the sub-set from this group. More women in Group A required oullet forceps $(\mu<0.05)$ whereas mid-forceps and Caesarean section rates were similar in the two groups. Fewer mothers in the infusion group had spontaneous vaginal delivery. We conclude shat infusion techniques are as effective as intermittent top-up epidurals and are well received by mothers in labour.
\end{abstract}

\section{Key words}

ANAESTHESIA: obstetric; ANALGESIA: epidural; PAIN MEASUREMENT: visual analogue pain scale.

From the Department of Anaesthesia, McMaster University, 1200 Main Street West, Room HSC-2V5, Hamilton, Ontario, L8N $3 Z 5$.

Address correspondence to: Dr. Smedscad.
Epidural analgesia, administered by intermittent "top-up" doses of local anaesthetic agent through an indwelling catheter, is routinely used to provide pain relief during childbirth. Continuous administration of the drug for maintenance of analgesia using a variety of infusion devices has been described in recent years. ${ }^{1-4}$ This method of administration has gained popularity with the introduction of safe, accurate mechanical infusion pumps. ${ }^{5}$

Epidural analgesia provides pain relief throughout Jabour, and can be converted to anaesthesia for operative delivery if necessary. The intermittent technique allows analgesia to wear off, and delays in top-up are not infrequent in busy obstetrical units. The efficacy of pain relief is thus lost.

Continuous administration by infusion has been described as providing smooth analgesia while avoiding delays in administration and hazards associated with bolus injections, ${ }^{6,7}$

Studies describing the use of continuous infusion techniques make no comparisons with the more traditional method of drug administration. ${ }^{8.9}$ This study was undertaken to compare the two methods of administration, using the same drug concentration, with regard to efficacy and outcome. The patients were all healthy primigravidae with uncomplicated pregnancies requesting epidural analgesia.

Satisfaction with pain relief was the primary focus of the study, but the effects on progress of labour, the mode of delivery and the well being of the baby were also recorded.

\section{Methods}

Sixty healthy primigravid women, aged 18 to 35 , of greater than 37 weeks gestation, gave written consent to participate in the study. The protocol was approved by the Hospital Ethics Committee. The parturients were randomized into two groups, A and B. An epidural catheter was inserted at $L_{2+3}$ when labour was well established. Five hundred $\mathrm{ml}$ of 0.9 per cent $\mathrm{NaCl}$ or lactated Ringer's solution were infused intravenously to all patients before 


\section{SENSORY BLOCK}

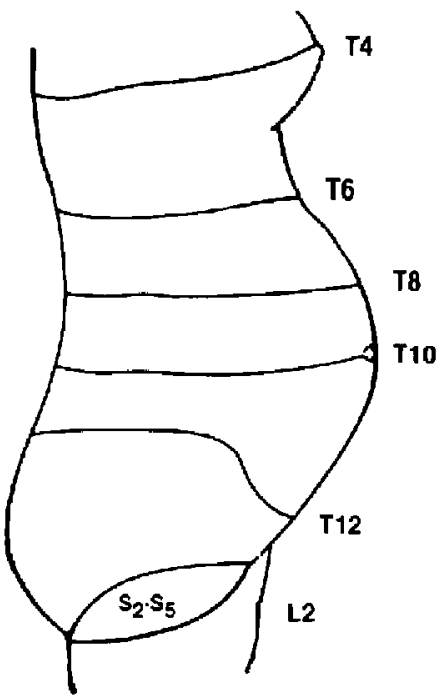

BROMAGE SCALE

\section{SCORE}

NIL

PARTIAL

ALMOST

COMPLETE

COMPLETE

\section{0}

1

2

Un:ablo to flex knoes

3
Free movement of leat.

Free movements of legs

Just able to flex knoes

Free movemenls of feet.

Unable to move legs or foet.

FIGURE 1 Bromage Scale (right panel). Derivative figure (left panel) used to record presence of unblocked segments.

epidural insertion. All patients received an initial injection of $12 \mathrm{ml}$ of 0.25 per cent bupivacaine in divided doses over ten minutes. Patients in Group A then received $8 \mathrm{ml}$ of 0.25 per cent bupivacaine per hour by continuous infusion using an IVAC 700 Infusion Pump. Patients in Group B received $8 \mathrm{ml}$ of 0.25 per cent bupivacaine per hour on a p.r.n. basis, as determined by the nurse. Sensory and motor blocks were assessed at hourly intervals using pinprick and the Bromage scale respectively. ${ }^{10}$ Unblocked segments were noted and marked by a cross on the dermatome figure (Figure 1). An "unblocked segment" was defined as an area where pain was not adequately relieved by the epidural. It was not specifically treated.

The parturients laboured in the lateral position, with gradual increase in head elevation as labour progressed. The adequacy of perineal block at the time of delivery was noted. Patients did not usually receive a "loading dose" for delivery. If instrumental delivery was necessary, suitable regional or general anaesthesia was given. Sixteen patients in Group B and fourteen in Group A received oxytocin infusion to stimulate labour. Prior to the insertion of the epidural catheter, the pain level was scored on a vertical visual analogue scale (VAS) ${ }^{6}$ The patient was shown a $10 \mathrm{~cm}$ long vertical unmarked line on a blank piece of paper and told that the bottom of the line represented no pain, the top "the worst pain you can imagine." The patient scored her pain before the epidural was inserted, one hour after its insertion, and 0.5-1 hour after completion of the delivery, while in the Recovery Room. A trained observer intervicwed the mothers the next day and obtained the score for the level of satisfaction with pain relief for both labour and delivery. Thus each mother completed 5 VAS pain score sheets. The length of labour, defined by the obstetrical staff as time from onset of regular contractions until delivery; the length of the second stage, defined as time from full cervical dilatation to delivery; the mode of delivery and reasons for forceps application or Caesarean section were noted. Fetal outcome was assessed by Apgar scores, umbilical cord blood gases and birth weight. Patients who needed other drugs were excluded from the study.

Maternal and fetal (cord) serum bupivacaine levels were measured in six patients in each group using a gas chromatographic method. This method is accurate to $0.016 \mathrm{ng} \cdot \mathrm{ml}^{-1}$. Statistical analysis was performed using Student's $t$ test and Chi-square analysis as appropriate. A level of $p \leq 0.05$ was considered significant. 
TABLE I Matemal characteristics (Mean \pm SD)

\begin{tabular}{|c|c|c|c|c|c|c|}
\hline Group & $\begin{array}{l}\text { Age } \\
\text { (years) }\end{array}$ & $\begin{array}{l}\text { Height } \\
\text { (cm) }\end{array}$ & $\begin{array}{l}\text { Weight } \\
(\mathrm{kg})\end{array}$ & $\begin{array}{l}\text { Gestalion } \\
\text { (weeks) }\end{array}$ & $\begin{array}{l}\text { Toial length } \\
\text { of labour } \\
\text { (n+in) }\end{array}$ & $\begin{array}{l}\text { Lengih of } \\
\text { second siage } \\
\text { (min) }\end{array}$ \\
\hline \multicolumn{7}{|l|}{$A$} \\
\hline$n=28$ & $25.6 \pm 5.3$ & $162.7 \pm 6.0$ & $72.8 \pm 9.2$ & 40 & $610.9 \pm 377.6$ & $93.31 \pm 78.5$ \\
\hline \multicolumn{7}{|l|}{ B } \\
\hline$n=29$ & $24.9 \pm 6.0$ & $165.5 \pm 5.7$ & $77.4 \pm 12.0$ & $39 \%$ & $498.8 \pm 306.8$ & $96.5 \pm 67.2$ \\
\hline
\end{tabular}

TABLE II Fetal outcome

\begin{tabular}{|c|c|c|c|c|c|c|c|}
\hline \multirow[b]{3}{*}{ Group } & \multicolumn{4}{|c|}{ Apgar scores } & \multirow{3}{*}{$\begin{array}{l}\text { Weighr* } \\
\text { (gm) }\end{array}$} & \multirow{3}{*}{$\begin{array}{l}\text { Cord venous } \\
p H^{*}\end{array}$} & \multirow{3}{*}{$\begin{array}{l}\text { Cord venous } \\
\mathrm{PO}_{2}(\mathrm{~mm} \mathrm{Hg})\end{array}$} \\
\hline & \multicolumn{2}{|l|}{$I \min$} & \multicolumn{2}{|l|}{$5 \min$} & & & \\
\hline & $7-10$ & $<7$ & $7-10$ & $<7$ & & & \\
\hline A & 29 & 0 & 29 & 0 & $3481.1 \pm 373.5$ & $7.35 \pm 0.05$ & $22.69 \pm 7.30$ \\
\hline B & 26 & 3 & 27 & 2 & $3469.2 \pm 585.9$ & $7.36 \pm 0.05$ & $27.00 \pm 7.98$ \\
\hline
\end{tabular}

* Mean $\pm \mathrm{SD}$

\section{Results}

The two groups were well 'matched for age, height weight, gestation and length of labour as shown in Table 1. One woman in Group A delivered before the epidural was established. One woman was excluded from the study because the catheter dislodged after several hours and was restarted, and she had received several doses of carbonated lidocaine. Twenty-eight participants from group $A$ are included for analysis of results. One patient in Group A, who had a Caesarean section, was found to have twins while in labour. Thus, there are 29 babies in Group A.

One woman in Group B was cxcluded from the study because she received carbonated lidocaine to combat groin pain. Twenty-nine patients in Group B are included for analysis. The babies' weights, Apgar scores and cord blood gases were similar in the two groups. (Table II -

TABLE III Sensory and motor block

\begin{tabular}{llll}
\hline Group & $\begin{array}{l}\text { Height } \\
\text { of block }\end{array}$ & $\begin{array}{l}\text { Maximum } \\
\text { motor score }\end{array}$ & $\begin{array}{l}\text { Missed } \\
\text { segthents }\end{array}$ \\
\hline A & $>\mathrm{T}_{6}=1$ & $0 / 1=22$ & 10 \\
$\mathbf{n}=28$ & $\begin{array}{l}\mathrm{T}_{6-10}=24 \\
<\mathrm{T}_{10}=3\end{array}$ & $2 / 3=6$ & \\
$\mathrm{~B}$ & $>\mathrm{T}_{6}=0$ & $0 / 1=23$ & 10 \\
$\mathrm{n}=29$ & $\mathrm{~T}_{6-10}=29$ & $2 / 3=6$ & \\
\hline & $<\mathrm{T}_{10}=0$ & & \\
\hline
\end{tabular}

No difference was observed in the efficacy of the block, analysed by Chi square $(\mathrm{p}>1.0)$. cord venous $\mathrm{pH}$ and $\mathrm{PO}_{2}$ only is included in the Table.) The degree of motor block and height of sensory block and incidence of missed segments were similar in the two groups (Table III).

Patients in both groups had high pain scores before the epidural was started (Group A: $8.58 \pm 1.16$, Group B: $8.96 \pm 0.83$ ) After receiving epidural analgesia, there was significant pain relief (Group A: $1.82 \pm 2.62$, Group B: $2.91 \pm 3.20$ ). The differences in pain scores between the two groups were not significant for the five assessments. VAS pain scores are shown in Figure 2.

The mode of delivery is shown in Table IV. The number of Caesarean sections and mid-forceps extractions was similar in both groups. The number of patients requiring outlet forceps was significantly greater in Group $\mathrm{A}(\mathrm{p}<0.05)$.

Table V shows that Group A patients received signifi-

TABLE IV Mode of delivery

\begin{tabular}{lllll}
\hline & $\begin{array}{l}\text { Spontaneous } \\
\text { vaginal } \\
\text { delivery }\end{array}$ & $\begin{array}{l}\text { Outler } \\
\text { forceps }\end{array}$ & $\begin{array}{l}\text { Mid. } \\
\text { forceps }\end{array}$ & $\begin{array}{l}\text { Caesarean } \\
\text { section }\end{array}$ \\
\hline Group & & 12 & 3 & 8 \\
$\mathrm{n}=28$ & 5 & 5 & 2 & 7 \\
$\mathrm{~B}$ & 15 & $<0.05$ & NS & NS \\
$\mathrm{n}=29$ & $<0.05$ & & &
\end{tabular}

$\mathrm{NS}=$ not significant 


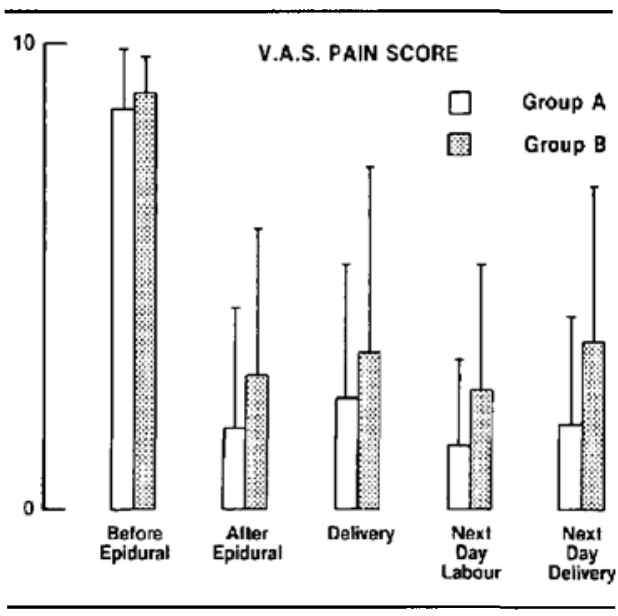

FIGURE 2 VAS pain scores \pm standard deviation is shawn in this Figure. There was no difference between group A and group B at any of the five scores. The difference in pain scores before epidural and after epidural was significant for both groups $(p<0.001)$.

cantly more bupivacaine than those in Group B ( $\mathrm{p}<$ $0.001)$. However, bupivacaine serum levels were similar in the two groups.

Clinically significant blood pressure drops (to $<100$ mmHg systolic) occurred in four patjents in Group A and two patients in Group B. Ephedrine was used to correct blood pressure drop after the initial dose of $12 \mathrm{ml} 0.25$ per cent bupivacaine in two patients in group $A$ and one patient in group $B$.

\section{Discussion}

The continuous infusion epidural technique has been found to be a safe and effective method of relieving the pain of childbirth." Some studies fail, however, to separate primigravid from multiparous patients. ${ }^{9,12}$ The pain of labour is more intense in primiparae, and the need for cpidural analgesia is probably greater in these patients. ${ }^{13}$

While other studies compare infusion of bupivacaine at one concentration and rate with intermittent top-up of a different concentration and volume, ${ }^{14}$ this study concentrated on selecting two uniform groups of primigravid women comparing two methods of administering the same drug in the same dosage. Both groups received the same initial dose, and had orders written for the same hourly dose.

\section{Pain relief}

The main focus of this study was satisfaction with pain relief. Melzak has reported that the pain of labour is extremely distressing. ${ }^{15}$ Pain scores are higher in primigravid than multiparous women. ${ }^{13}$ Epidural analgesia reduces the stress responses of labour, and decreases the deleterious effects of increased circulating catecholamines on the cardiovascular system and uterine activity. Complete pain relief is not achieved for all parturients, but most are greatly relieved by this method. ${ }^{16} \mathrm{~A}$ variety of local anaesthetic drugs and doses can be used to provide epidural analgesia for parturition. In our unit 0.25 per cent bupivacaine, $6-12 \mathrm{ml} \cdot \mathrm{hr}^{-1}$, is routinely used. Top-ups are delegated to specially trained nurses. We chose not to alter usual practice for the purpose of this study. Thus, 0.25 per cent bupivacaine $8 \mathrm{ml} \cdot h^{-1}$ was chosen as an appropriate dose.

A vertical VAS was used to score pain levels. ${ }^{17}$ The scoring was done immediately after a contraction when labour was well established and the mothers had requested epidural analgesia. Before the epidurals were inserted all patients scored eight to ten on the scale, attesting to the significant degree of distress they experienced. After the epidural was established, the pain was greatly relieved in all subjects and the discomfort which remained was variously described as pressure, backache or focal pain. Matuskova et al. ${ }^{18}$ discuss the adequacy of pain relief related to the placement of the epidural catheter. With higher placement $\left(T_{12}-L_{1}\right)$ the pain relief is better, presumably because the $T_{10}-L_{1}$ nerve roots which transmit uterine pain are more easily reached and blocked. The volume of infusate rather than the amount of drug given is important. Kenepp ${ }^{19}$ showed that efficacy of the block is related to the number of dermatomes blocked and found that $16 \mathrm{ml}$ of 0.125 per cent bupivacaine gave superior

TABLE V Bupivacaine serum levels (Mean \pm SD)

\begin{tabular}{|c|c|c|c|c|c|c|c|}
\hline Group & $\begin{array}{l}\text { Bupivacaine } \\
\text { dose (mg) }\end{array}$ & & $\begin{array}{l}\text { Maternal } \\
\text { bupivacaine } \\
\text { (ng } L^{-1} \text { ) }\end{array}$ & & $\begin{array}{l}\text { Cord } \\
\text { bupivacaine } \\
\left(n g-L^{-1}\right)\end{array}$ & & $\begin{array}{l}F / M \\
\text { ratio }\end{array}$ \\
\hline A & $160.9 \pm 70.9$ & $\mathbf{n}=\mathbf{2 8}$ & $770 \pm 220$ & $n=6$ & $155 \pm 94$ & $n=6$ & 0.20 \\
\hline $\mathrm{B}$ & $87.2 \pm 53.8$ & $\mathbf{n}=29$ & $1427 \pm 765$ & $n=6$ & $272 \pm 184$ & $n=6$ & 0.19 \\
\hline p & $<0.001$ & & NS & & NS & & \\
\hline
\end{tabular}


pain relief to $8 \mathrm{ml}$ of 0.25 per cent or $4 \mathrm{ml}$ of 0.5 per cent of the same drug. $\mathrm{Li}$ et al. ${ }^{14}$ reported that optimum pain relief was seen with an infusion rate of $10 \mathrm{ml} \cdot \mathrm{hr}^{-1}$ of 0.125 per cent bupivacaine. Taylor ${ }^{4}$ reported good pain relief with $6 \mathrm{ml} 0.25$ per cent bupivacaine. Nadeau es al. ${ }^{2}$ used $7 \mathrm{ml}$ of 0.25 per cent bupivacaine by infusion and obtained superior pain relief compared with intermittent doses of the same concentration, but the patients were not standardized for parity or reasons for epidural insertion. In order to achieve optimum results in any given patient, one must experiment with various concentrations and volumes and be prepared to alter infusion rates or give added boluses as needed.

Our mothers were interviewed the day following their delivery by an independent observer and asked about their perception of pain relief. It is interesting to note that the score for labour was similar the next day, suggesting that the measurements are reproducible.

\section{Sensory and motor block}

The height of the sensory block was the same in the two groups. Ten patients in each group had "missed segments." This contributed to the dissatisfaction with pain relief. A missed segment was defined in this study as a focal area where pain was not relieved, including a unilateral block or pressure and back pain. The occurrence of missed segments is probably related to the position of the catheter and the anatomy of the epidural space, rather than the way the drugs are given. ${ }^{18,19}$

Abboud $^{21}$ suggested that the chances of developing a motor block is less with continuous infusion techniques. We found that with 0.25 per cent bupivacaine the incidence and density of motor block was the same in the two groups. This is in ugreernent with other published studies where lower concentrations of the drug were used. ${ }^{14}$

\section{Hypotension}

All patients were given an intravenous volume load of 500 $\mathrm{ml}$ of lactated Ringer's solution or sodjum chloride, before the epidural was started. The incidence of hypotension was similar in the two groups. Hypotension was defined as a drop in blood pressure below $100 \mathrm{mmHg}$. This occurred in approximately ten per cent of patients after the initial dose was given. In all cases the $12 \mathrm{ml}$ of 0.25 per cent bupivacaine were given in $3 \mathrm{ml}$ increments over 10-15 minutes. Two patients in each group did not spontaneously revert to normal blood pressure with improved positioning and required ephedrine. We did not observe further hypotensive episodes, either with top-ups or with continuous infusion. We carefully avoided positioning patients in such a way that aorto-caval compression could occur throughout labour. The initial hypoten- sion is probably related to relative dehydration and peripheral vasodilatation as the sympathetic block takes effect.

\section{Mode of delivery}

A similar number of patients in each group required Caesarean section. The reasons given were cephalopelvic disproportion (CPD), or failure to progress. There was one case of fetal distress due to abruptio placenta in Group B, and onc fetus in each group had heart rate changes and loss of variability associated with CPD, prompting the decision for operative delivery. The frequency of Caesarean section in this study corresponds to the average section rate in our unit ( 26 per cent). Two babies in Group B who were delivered vaginally had Apgar scores of five and six. No reason for the low scores were apparent.

The length of labour and the length of the second stage were similar in the two groups. The second stage varied from 0.5 hour to over four hours in both groups, with the average time being approximately 90 minutes. Thus, the length of the second stage per se was not used as an indication for forceps application. The results, therefore, suggests that the mode of drug administration did not influence the progress of labour.

The incidence of forceps delivery with epidural analgesia has previously been described as anywhere from 15-71 per cent. ${ }^{11.22}$ Many factors contribute to the wide discrepancy in these figures. Parity is a factor, as forceps delivery is more common in primiparae than in multiparae. The reasons for choosing epidural analgesia in labour is important. If labour is progressing normally and epidural analgesia is chosen for pain relief only, the incidence of forceps delivery is not increased ${ }^{23}$ Some of the earlier studies which reported high forceps rates did not separate normal from abnormal labour. ${ }^{24}$ Variations and preferences in obstetrical practice must be taken into account. In our unit, mothers with epidurals are encouraged to try to push their babies out and they are allowed to prolong the second stage if this is not contraindicated. Fetal monitoring is routine. Even so, there are variations in practice. Our study was not standardized for this variable.

Phillips and Thomas ${ }^{25}$ reported a higher incidence of forceps deliveries in primigravid patients whose epidural was allowed to wear off so thcy could push. Thcy attributed this to an increase in sympathetic reflex activity and circulating catecholamines causing impairment of uterine activity. Continuous epidural analgesia may not prolong the second stage when compared with control groups without epidurals. Bailey and Howard ${ }^{26}$ reported a 24 per cent forceps rate in 5.71 primigravidae in 1977 prior to instituting an epidural service, and compared this 
to a rate of 26.7 per cent in another 634 primigravid patients in the same hospital in 1980 when the epidural rate was 72.4 per cent. Studd et al. ${ }^{27}$ showed that allowing a longer second stage in mothers with epidural block would reduce the incidence of rotational forceps delivery.

Maresh et al ${ }^{28}$ reported that allowing the second stage to progress from 27 minutes to 123 minutes was associated with an increase in spontaneous deliveries and a decrease both in rotational and total forceps deliveries in 76 primigravid patients with epidural analgesia.

In our study 12 patients receiving continuous infusion epidurals needed outlet forceps delivery, compared to five in the top-up group. Reasons for use of forceps were given as inability of the patient to push, fatigue or matemal exhaustion. In four cases in Group $A$ and two cases in Group B, fetal heart rate changes were cited as reasons for using forceps, yet all these babies had normal Apgar scores. The difference in incidence of outlet forceps was significant in this study.

Mid-cavity rotational forceps were used due to transverse or persistent postcrior positions. Fetal heart rate decelerations prompted the decision to apply Kielland's forceps in two cases in each group.

The reports on the relationship between the use of epidural analgesia and forceps delivery rates thus continue to be conflicting. We have no doubts that obstetrical practice patterns are determining factors. Perhaps the way the epidural is administered is important. It is thought that motor block of the pelvic floor contributes to midforceps rates. Walton and Reynolds found a significant increase in the applications of Kielland's forceps amongst primiparae who received sitting top-ups. ${ }^{23}$ We found no dilference in mid or rotational forceps rates in our two groups. A "loading dose" was not given before delivery, so patients in Group B did not receive top-ups after full dilatation. Patients in either group would have received a top-up dose when the decision was reached to apply forceps, if the perineal analgesia was inadequate for instrumental delivery. Thus, in both groups, two patients received a top-up for outlet forceps and two patients for rotational forceps.

Regardless of the mode of delivery, the outcome for the babies was favourable in all our cases, confirming that the total obstetrical management of the patient is far more important than slight variations in anaesthctic technique.

\section{Drug levels}

We measured plasma levels of bupivacaine in six patients in each group. The cost of these estimations prohibited such tests in the entire study population. Matemal blood levels of bupivacaine were $770 \pm 220 \mathrm{ng} \cdot \mathrm{L}^{-1}$ in group $A$ mothers and $155 \pm 94 \mathrm{ng} \cdot \mathrm{L}^{-1}$ in the babies. These levels are in agreement with several other studies of infusion epidurals. ${ }^{6,9.21}$ The fetal/maternal ratio of 0.2 and 0.19 was similar in the two groups. In contrast the maternal plasma level in Group B was $1427 \pm 765 \mathrm{ng} \cdot \mathrm{L}^{-1}$ and in Group $B$ babies it was $272 \pm 184 \mathrm{ng} \cdot \mathrm{L}^{-1}$. Due to the small number of estimations this difference was not significant. The maternal blood level in Group B must be related to the time lapse since the last top-up. This was not standardized.

It is significant, however, that patients in Group A received twice as much drug during the course of the labour than Group B patients $(160.9 \pm 70.9 \mathrm{mg}$ vs $87.2 \pm$ $53.9 \mathrm{mg}$ ). This phenomenon has also been described by others. ${ }^{12,14}$ The orders read: " $8 \mathrm{ml} 0.25$ per cent bupivacaine per hour pm" in Group B, and top-ups were given at the discretion of the nurses as is usual in our unit. The difference in the total amount of drug given must be due to Group A patients getting the amount of drug sec by infusion rate, whereas Group B did not receive $8 \mathrm{ml}$ every hour. This confirms Taylor's assertions that top-up epidurals are subject to fluctuations both in pain relief and frequency of top-ups.?

In spite of the patients having received a large amount of bupivacaine, the blood levels in both the mother and the umbilical cord were low in Group $A$. The uptake and distribution and perhaps metabolism of the drug in the mother is thus influenced by the mode of dng delivery. When infused slowly, bupivacaine does not accumulate in the blood to the same degree. ${ }^{6}$ The drug administered this way is, therefore, less likely to cause toxicity.

Intrayascular or intrathecal infusion or injection of drugs did not occur in this study. We cannot, therefore, draw any conclusions regarding safety of the method of administration. Case reports or a larger study are needed to determine safety. Safety precautions should be taken in the same way, regardless of the method of administration. ${ }^{5}$

In summary, we conclude that infusion techniques are as effective as intermittent top-up epidurals and are well received by mothers in labour. The parturients received significantly more drug with infusion but the blood levels in both mother and baby remained low. Fewer mothers in the infusion group had spontaneous vaginal delivery.

\section{Summary}

This study compared the standard method of intermittent "top-up" doses with a continuous infusion technique of epidural analgesia for labour and delivery in primiparae with regard to efficacy and outcome. After an initial $12 \mathrm{ml}$ dose, Group A received $8 \mathrm{ml} 0.25$ per cent bupivacaine per hour by infusion pump, and Group B received $8 \mathrm{ml}$ boluses hourly on a p.r.n. basis. 
The groups were comparable with regard to gestation, length of labour and fetal outcome. Sensory and motor block and incidence of missed segments were the same in both groups.

Parturients in both groups were satisfied with their pain relief for both labour and delivery. The results of visual analogue pain scores were reproducible the next day.

Mothers in Group A received more drug than those in Group B $(p<0.001)$ but plasma bupivacaine levels remained low in the maternal and umbilical cord samples from this group. More women in Group A required outlet forceps ( $p<0.05$ ), whereas midforceps and Caesarean section rates were similar in the two groups.

\section{Acknowledgements}

We wish to thank Astra Pharmaceuticals for funding this study and IVAC for supplying the pump. We express our gratitude to the nurses in Labour and Delivery at McMaster Medical Centre for their cooperation. Thanks are due to Miss Mary Helen Blackhall for carrying out pain assessments, and to Mrs. Valerie Cannon for typing the manuscript.

\section{References}

I Spoerel WE, Thomas A, Gerula GR. Continuous epidural analgesia: expericnce with mochanical injection devices. Can Anaesch Soc J 1970; 17: 37-51.

2 Glover DJ. Continuous epidural analgesia in the obstetric patient. a feasibility study using a mechanical infusion pump. Anaesthesia 1977; 32: 499-503.

3 Evans KRL, Carrie LES. Continuous epidural infusion of bupivacaine in labour: a simple method. Anaesthesia 1979; 34: 310-5.

4 Taylor $H J C$. Clinical experience with continuous epidural infusion of bupivacaine at $6 \mathrm{ml}$ per hour in obstetrics. Can Araesth Soc 5 1983; 30: 277-85.

5 Morison DH, Smedstad KG. Editorial. Continuous infusion epidurals for obstetric analgesia. Can Anzesth Soc J 1985; 32: 101-4.

6 Matouskova A, Hanson B. Continuous mini-infusion of bupivacaine into the epidural space during labor. Part II: Blood concentration of bupivacainc. Acta Obstet Gynecol Scan 1979; Suppl 83: 31-41.

7 Taylor HJC. Choice of analgesia/anaesthesia during labour and delivery. Clinical and Investigative Medicine $1985 ; 8: 345-51$.

8 Matouskova A. Epidural analgesia: continuous miniinfusion of bupivacaine into the epidural space during labor. Acta Obstet Gynecol Scan 1979; Suppl 83: 5-52.

9 Rosenblatr $R$, Wright $R$, Denson $D, R a j P$. Continuous epidural infusions for obstetric analgesia. Regional Anesthesia 1983; 8: 10-5.
10 Bromage PR, Burfort MF, Crowell DE, Penigrew RT. Quality of epidural blockade. I: Influence of physical factors. Br J Anaesth 1964; 36: 342-52.

11 Matouskova A, Dottori O, Forssman L, Victorin L. An improved method of epidural analgesia with reduced instrumental delivery rate. Acta Obstet Gynecol Scand 1979 : Suppl 83: 9-13.

12 Nadeau $S$, Elliott $R D$. Continuous bupivacaine infusion during labour: effects on analgesia and delivery. Can Anaesth Soc J 1984; 31: S70-1.

13 Melzack R, Taenzer P, Feldman P. Kinch RA. Labour is still painful after prepared childbirth training. Can Med Assoc J 1981; 125: 357-63.

$14 L i D F$, Rees $G A D$, Rosen $M$. Continuous extradural infusion of $0.0625 \%$ of $0.125 \%$ bupivacaine for pain relief in primigravid labour. Br J Anaesth 1985; 57: 264-70.

15 Melzack $R$, Kinch $R$, Dobkin P, Lebrun M, Taenzer P Severity of labour pain: influence of physical as well as psychologic variables. Can Med Assoc J 1984; 130 : 579-84.

16 Daughty A. Lumbar epidural analgesia - the pursuit of perfection. With special reference to midwife participation. Anaesthesia 1975; 30: 741-51.

17 Grossi E, Borghi C, Montanari $M$. Measurement of Pain: comparison between visual analog scale and analog chromatic continuous scale. Advances in Pain Research and Therapy 1985; 9: 371-6.

18 Matouskova A, Hanson B, Rosmark $U$. Continuous miniinfusion of bupivacaine into the epidural space during labor. Acta Obstel Gynecol Scand 1979; Suppl 83: 15-29.

19 Kenepp NB, Cheek TG, Gursche BB. Bupivacaine: continuous infusion epidural analgesia for labor. Anesthesiology 1983; Suppl 59: $\wedge 407$.

20 Blomberg $R$. Epiduroscopy - endoscopy of the epidural space. Acta Anaesthesiol Scand 1985; Suppl 80: 66.

21 Abboud TK, Afrasiabi A, Sarkis $F$ et al. Continuous infusion epidural analgesia in parturients receiving bupivacainc, chloroprocaine, or lidocaine - matemal, fetal, and neonatal effects. Anesth Analg 1984; 63: 421-8.

22 Houit IJ, MacLellan AH, Carrie LES. Lumbar epidural analgesia in labour: relation to fetal malposition and instrumental delivery. Br Med J 1977; 1: 14-6.

23 Walton $P$, Reynolds $F$. Epidural analgesia and instramental delivery. Anaesthesia 1984; 39: 218-23.

24 Doughty $A$. Selective epidural analgesia and the forceps rate. Br J Anaesth 1969; 41: 1058-62.

25 Philips KC, Thomas TA. Second stage of labour with or without extradural analgesia. Anaesthesia 1983; 38: 972-6.

26 Bailey PW, Howard FA. Forum. Epidural analgesia and forceps delivery: laying a bogey. Anaesthesia 1983; 38: $282-5$. 
27 Studd JWW, Crawford IS, Duignan NM, Rowbotham CJF, Hughes $A O$. The effect of lumbar epidural analgesia on the rate of cervical dilatation and the outcome of labour of spontaneous onset. Br J Obstet Gynaecol 1980; 87: 1015-21.

28 Maresh $M$. Choong $K-H$, Beard $R W$. Delayed pushing with lumbar cpidural analgesia in labour. Br J Obstet Gynaecol 1983; 90: 623-7.

29 Hanson AL, Hanson B. Continuous mini-infusion of bupivacaine into the epidural space during lahour. Experience from 1000 deliveries. Regional Ancsthesia 1985; 10: $139-44$

\section{Résumé}

Cette étude compare la technique de perfusion continue à la sechnique de "rajout" intermittente de doses de 0.25 pour cent de bupivacaine pour l'analgésie épidurale tors du travail et l'accouchement chez des primipares en bonte santé. Soixante femmes éraient randomisées en deux groupes, groupe A (perfusion continue) et groupe $B$ (technique intermittente de rajout). Vingt-huit patientes du groupe A et 29 du groupe $B$ ant complété l'étude. On a comparé les groupes en fonction de la sal isfaction face au soulagement de la douleur lors du travail et de l'accauchement tel que mesuré par le Visual Analogue Scale à cinq étapes pendant et après l'accouchement. Il n'y avait aucune différence entre les groupes aux différentes êtapes étudiées. La différence dans l'échelle de douleur avant et après épirurale était significative dans les deux groupes $(p<0.01$ ). $L$ 'incidence de bloc segmentaire incomplet, le degré de blocage moteur, la hauteur du blocage sensariel, la longueur du travail et l'issu (outcome) finai pour le bébé étaient similaires dans les deux groupes. Le niveau plasmatique de bupivacaïne était mesuré chez six patientes de chaque groupe. Les mères du groupe $A$ ont reçu plus de drogue que celles du groupe $B$ (p $<$ 0.01 ) et le niveau de bupivacaïne plasmatique est demeuré bas chez la mère et dans te cordon ambilical. Plus des femmes du groupe $A$ ont requis l' application de forceps $(p<0.05$ ) alors que l' incidence d' application des forceps en position moycnne et la césarienne étaient similaires dans les deux groupes. Peu de mères dans le groupe à perfusion ont prèsenté un accouchement vaginal spontané. On conclut que la technique de perfusion est aussi efficace que la technique de rajout (rajout intermittente) et qu' elle est bient tolerée par les mères lors du travail. 